\title{
De relatie met de zorgvrager gaat altijd boven de inzet van interventies
}

W

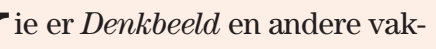
bladen op naslaat kan er niet omheen: in het zoeken naar een zo goed mogelijke begeleiding van mensen met dementie bewandelen we het pad van de interventie. De boodschap is telkens min of meer: doe dit op die manier en je zal zien dat de effecten positief zijn. Daar is niets mis mee, zolang we maar nooit vergeten dat een goed contact met de zorgvrager de basis is van alles en mogelijk zelfs doorslaggevend voor de impact van de hulpverlening.

De grote aandacht voor (gestandaardiseerde) interventies heeft veel te maken met het nog altijd sterk aanwezige medische denkkader in de dementiezorg. Aanpak van symptomen en gedragsproblemen staat voorop. Zeker in het onderzoek lijkt 'minder problemen' veruit de belangrijkste maatstaf voor goed werk: minder agitatie, minder apathie, minder depressie, minder desoriëntatie... De behoefte aan controleerbaarheid en meetbaarheid heeft hier zeker iets mee te maken. Maar een dergelijke eenzijdigheid is ook de zorgsector zelf niet vreemd. De eenvoudigste handelingen krijgen tegenwoordig het label 'interventie', 'therapie' of 'behandeling'. En nog veel meer zaken 'werken therapeutisch'. Dat klinkt als een eretitel en streelt ons professionele ego.

Een neveneffect van dit denken in interventies is dat het ons gevoelig maakt voor de commerciële markt. Steeds vaker verschijnen producten die heilzame effecten beloven. Lijkt makkelijk en efficiënt, want je kan meteen aan de slag. Wellicht het grootste probleem van een te sterk interventionistische manier van denken is echter dat ons handelen in de uitvoeringsmodus komt te staan. De vraag: 'Hoe moet ik het doen?' wordt belangrijker dan de vraag: 'Wat telt voor deze persoon op dit moment?' We verliezen daarmee niet alleen de aansluiting met de persoon tegenover ons, maar ondermijnen zo ook onze authenticiteit en creativiteit in het omgaan met de situatie.

En dat terwijl recent onderzoek doet vermoeden dat aansluiting bij iemands persoonlijke voorkeuren het best de effecten van interventies verklaart. Dat geen enkele interventie ook maar enig positief effect heeft wanneer de relatie niet goed zit. En dat zelfs in psychotherapie de belangrijkste werkzame factor de kwaliteit van de relatie is. De cliënt is het meest geholpen wanneer hij zich begrepen en gerespecteerd voelt door iemand die hij als echt ervaart.

Laten we ons dus goed bewust blijven van het belang van het gewone, authentieke, empathische en respectvolle menselijk contact. Op die basis groeien vertrouwen, betrokkenheid en bereidheid. In vele kleine contactmomentjes bouwen we aan een relatie, te beginnen met een vriendelijke groet in het voorbijgaan. Zo werkt het, niet alleen bij dementie: zien en gezien worden. Spullen van vroeger kunnen helpen invulling te geven aan het con- tact. Maar laten we die spullen dan wel gewoon spullen noemen en laten het geen therapeutische hulpmiddelen worden. Net zoals bezigheden als oude foto's bekijken, favoriete muziek opzetten, samen zingen, het licht of de buitenlucht opzoeken, contact hebben met dieren of ruiken aan bloemen mensen deugd kunnen doen. Zoals ze dat altijd gedaan hebben tijdens een leven - zonder dat ze toen ooit interventies heetten... En laten we terwijl we dergelijke dingen met iemand doen, vooral oog hebben voor wie deze persoon is, wat voor hem of haar betekenisvol is en wat hij of zij voor anderen wil en kan betekenen.

Wil dit zeggen dat we dan alle interventies, het onderzoek ernaar en de ontwikkeling ervan maar overboord moeten gooien? Uiteraard niet. Weten wat je mogelijkheden zijn, wat je doet en waarom is een essentieel kenmerk van professionaliteit. Uiterst belangrijk, omdat we nu eenmaal met kwetsbare mensen werken. Maar de belangrijkste interventie is wellicht aandachtig contact maken. Vertrouw daarbij op je eigen persoonlijke rijkdom om samen met de persoon met dementie invulling te geven aan het moment.

PATRICK VERHAEST IS REDACTEUR VAN DENKBEELD, PROJECTMEDEWERKER BIJ HET EXPERTISECENTRUM DEMENTIE VLAANDEREN EN COÖRDINATOR VAN DE OPLEIDING TOT BEGELEIDER-ANIMATOR AAN DE VSPW TE MOL. 